\title{
PENGARUH KOMITMEN ORGANISASIONAL DAN DISIPLIN KERJA TERHADAP PRESTASI KERJA KARYAWAN PADA PT TELKOM AKSES AREA SUMATERA UTARA PEMATANG SIANTAR
}

\author{
Frans Eka Putra Harefa1, Darna Sitanggang ${ }^{2}$ \\ 1,2 Universitas Katolik Santo Thomas Medan J1. Setia Budi No. 479F, 20132, Indonesia \\ e-mail: darna.sitanggang@gmail.com
}

\begin{abstract}
The purpose of this study is to determine the influence of organizational commitment and working discipline towards employees achievement at PT. Telkom Access Pematang Siantar, North Sumatera Territory. The analytical method that was used is multiple linear regression analysis. The amount of population in this study is 284 employees working PT. Telkom Access Pematang Siantar, North Sumatera Areal. The sampling amount is 166 respondens by using Proportional Random Sampling. The data was collected by using questionnaire, interview, and documentation study. From the result of the research, it is discovered that the coefficient of determination (R Square) is 0,820 or $82 \%$. This means that the variations in employee working performance can be determined by variations in organizational commitment and working discipline by $82 \%$, while the rest $18 \%$ is determined by other variables not included in this research, such as motivation, leadership, communication, and training program. The multiple linear regression equation obtained from the data processing result is $Y=4.182+0.420\left(X_{1}\right)+0.615\left(X_{2}\right)+e i$, which means that organizational commitment and working discipline are positively affecting the employee performance at PT. Telkom Access Pematang Siantar, North Sumatera Territory. Simultaneously, organizational commitment and working discipline are significantly affecting the employees achievement at PT. Telkom Access Pematang Siantar, North Sumatera Areal. Partial Testing shows that organizational commitment and work discipline are having a positive and significant result on employees achievement at PT. Telkom Access Pematang Siantar, North Sumatera Areal. Meanwhile, working discipline is the most influencing variable towards employees achievement at PT. Telkom Access Pematang Siantar, North Sumatera Areal, with higher regression coefficient value which is 0,615 . This suggests the company to give their attention to organizational commitment and work discipline, because both of those variables are positively and significantly affecting employees performance.
\end{abstract}

Keywords : Organizational Commitment, Working Discipline, Working Achievement

\section{PENDAHULUAN}

Sumber daya manusia memegang peranan yang sangat penting dalam suatu perusahaan, baik perusahaan swasta maupun instansi pemerintah. Sumber daya manusia yang dimaksud adalah orang-orang yang memberikan tenaga, pikiran, kreativitas dan usahanya didalam menjalankan kegiatan perusahaan. Komitmen karyawan merupakan salah satu hal yang tidak kalah pentingnya untuk mencapai prestasi kerja yang baik.

Karyawan yang bekerja didalam suatu perusahaan harus memiliki komitmen yang kuatterhadap organisasi karena komitmen organisasional merupakan tingkat kepercayaan dan penerimaan tenaga kerja terhadap tujuan organisasi dan mempunyai keinginan untuk tetap ada dalam organisasi. Maka dari itu, dukungan dari fungsi-fungsi sumber daya manusia lainnya tidak boleh diabaikan.

Adanya kebutuhan karyawan yang dapat terpenuhi melalui pekerjaan yang dilakukannya akan menimbulkan suatu komitmen dari pihak karyawan maupun perusahaan yang akan memberikan pengaruh besar terhadap kelangsungan hidup perusahaan. Jika

Pengaruh Komitmen Organisasional Dan Disiplin Kerja Terhadap Prestasi Kerja Karyawan Pada PT. Telkom Akses Area Sumatera Utara Pematang Siantar. Oleh : Frans Eka Putra

Harefa, Darna Sitanggang 


\section{Volume 20 Nomor 2, September 2020}

komitmen seseorang karyawan terhadap perusahaannya tinggi maka prestasi kerja juga akan tinggi dan sebaliknya.

Menurut Robbins (2012) komitmen organisasi merupakan tingkat sejauh mana seseorang karyawan memihak sebuah organisasi serta tujuan-tujuan dan keinginannya untuk mempertahankan keanggotaannya dalam organisasi tersebut. Dengan adanya konsep komitmen organisasi, karyawan akan merasa bahwa ia adalah bagian perusahaan, berusaha menjadi karyawan yang terbaik, tidak menunda-nunda pekerjaan, tidak mangkir dari jam kerja dan merasa ia memiliki tanggung jawab kepada perusahaan. Komitmen dikatakan positif apabila seorang karyawan mampu menunjukkan minat yang tinggi untuk mau belajar, meningkatkan pengetahuaannya, dan mentransfer ilmunya kepada yang lain. Hal lain juga yang memiliki peranan penting dalam pencapaian prestasi kerja adalah disiplin kerja.

Disiplin kerja sangat penting bagi perusahaan karena disiplin kerja mempunyai manfaat mendidik karyawan agar mematuhi dan menaati peraturan-peraturan, prosedur bekerja yang ditetapkan oleh perusahaan agar karyawan memiliki kinerja yang baik.Semakin disiplin seorang karyawan maka semakin tinggi pula produktivitas kerja dan kinerja di perusahaan. Jadi, sulit bagi perusahaan dapat berprestasi dengan tinggi tanpa melaksanakan disiplin yang tinggi.

Disiplin yang baik mencerminkan besarnya tanggung jawab seseorang terhadap tugas-tugas yang diberikan kepadanya. Hal ini mendorong gairah kerja, semangat kerja dan terwujudnya tujuan perusahaan. Melalui disiplin akan tercermin kekuatan, karena biasanya seseorang yang berhasil didalam karyanya adalah mereka yang memiliki disiplin yang tinggi. Untuk mewujudkan tujuan perusahaan, harus dibangun dan ditegakkan kedisiplinan pada karyawan di perusahaan tersebut. Memelihara kedisiplinan yang baik adalah hal yang sulit, karena banyak indikator-indikator yang mempengaruhinya. Indikator-indikator tersebut antara lain teladan pimpinan, pengawasan yang melekat, sanksi hukuman, ketegasan, peraturan dan hubungan kemanusiaan sehingga sangat jelas kontrol dari atasan merupakan salah satu faktor dalam menciptakan disiplin kerjakaryawan pada suatu organisasi. Jadi, kedisiplinan merupakan kunci keberhasilan dalam suatu perusahaan tertentu dalam mencapai tujuannya.

Prestasi kerja merupakan tolak ukur didalam melihat kemampuan seorang karyawan dalam melakukan pekerjaanya. Namun demikian, prestasi kerja dapat dicapai dengan adanya komitmen organisasi dan disiplin kerja. Prestasi kerja mempunyai peran yang sangat penting dalam mewujudkan tujuan perusahaan, prestai kerja dapat diketahui sebagai suatu hasil kerja yang dicapai seseorang didalam melaksanakan tugas dan wewenang yang diberikan kepadanya. Prestasi kerja adalah hasil kerja yang dicapai seseorang dalam melaksanakan dan menyelesaikan pekerjaan yang dibebankan kepadanya.

Hasil penelitian Dyah Ayu (2014) dengan judulPengaruh Komitmen Organisasional, Disiplin Kerja Karyawan terhadap Prestasi Kerja Karyawan pada PT Pabrik Gula Toelangan Sidoarjomenyimpulkan bahwa Komitmen Organisasional dan Disiplin Kerja berpengaruh positif dan signifikan terhadap Prestasi Kerja.

Penelitian Ana Puspita (2013) dengan judul Pengaruh Komitmen Organisasional, Disiplin Kerja terhadap Prestasi Kerja Karyawan padaDinas Kebersihan dan Pertamanan Surakarta menyimpulkan bahwa komitmen organisasional berpengaruh positif tetapi tidak signifikan terhadap Prestasi Kerja dan Motivasi Kerja berpengaruh positif dan signifikan terhadap Prestasi Kerja Karyawan.

Penelitian Irfan Nanda (2013) dengan juduli Pengaruh Komitmen Organisasi Terhadap Prestasi Kerja pada Karyawan AJB Bumi Putera Kantor Cabang Batu, menyimpulkan bahwa ada pengaruh secara positif dan signifikan dari variabel Komitmen Organisasional terhadap Prestasi Kerja. 


\section{Volume 20 Nomor 2, September 2020}

Telkom Akses merupakan salah satu anak perusahaan Telkom yang bergerak di bidang konstruksi pembangunan dan manage service infrastruktur jaringan. PT Telkom Akses didirikan pada tanggal 12 Desember 2012.PT Telkom Akses (PTTA) merupakan anak perusahaan PT Telekomunikasi Indonesia, Tbk (Telkom) yang sahamnya dimiliki sepenuhnya oleh Telkom. PTTA bergerak dalam bisnis penyediaan layanan konstruksi dan pengelolaan infrastruktur jaringan.

Pendirian PTTA merupakan bagian dari komitmen Telkom untuk terus melakukan pengembangan jaringan broadband untuk menghadirkan akses informasi dan komunikasi tanpa batas bagi seluruh masyarakat indonesia. Telkom berupaya menghadirkan koneksi internet berkualitas dan terjangkau untuk meningkatkan kualitas sumber daya manusia sehingga mampu bersaing di level dunia.

Saat ini Telkom tengah membangun jaringan backbone berbasis Serat Optik maupun Internet Protocol (IP) dengan menggelar 30 node terra router dan sekitar $75.000 \mathrm{Km}$ kabel Serat Optik. Pembangunan kabel serat optik merupakan bagian dari program Indonesia Digital Network (IDN) 2015. Sebagai bagian dari strategi untuk mengoptimalkan layanannya, Telkom mendirikan PT. Telkom Akses.

Kehadiran PTTA diharapkan akan mendorong pertumbuhan jaringan akses broadband di indonesia. Selain Instalasi jaringan akses broadband, layanan lain yang diberikan oleh PT Telkom Akses adalah Network Terminal Equipment (NTE), serta Jasa Pengelolaan Operasi dan Pemeliharaan (O\&M - Operation \& Maintenance) jaringan akses pita lebar.

Kelengkapan fasilitas yang diberikan PT Telkom Akses kepada karyawan bertujuan untuk melancarkan segala proses pekerjaan yang akan dilaksanakan di perusahaan tersebut. Dalam kata lain, agar seluruh karyawan memiliki komitmen yang dikemukakan para ahli, PT Telkom Akses komitmen afektif dan normatif sebagai landasan komitmen yang utama untuk diterapkan di perusahaan tersebut. Dengan tujuan agar para karyawan melibatkan diri mereka didalam perusahaan tersebut.

PT Telkom Akses sendiri terbagi atas beberapa wilayah untuk mempermudah proses penjangkauan wilayah diseluruh Indonesia. salah satunya PT Telkom Akses Area Sumatera Utara Pematang Siantar yang menjadi tempat penelitian penulis.

Untuk melihat gambaran tentang komitmen organisasi, penulis menampilkan perputaran karyawan pada PT. Telkom Akses Area Sumatera Utara Pematang Siantar.

Tabel. 1 Daftar Perputaran Karyawan PT Telkom Akses Area Sumatera Utara Pematang Siantar

\begin{tabular}{|c|c|c|c|}
\hline Tahun & Jumlah Karyawan (orang) & Keluar (orang) & Masuk (orang) \\
\hline 2015 & 275 & 17 & 23 \\
\hline 2016 & 281 & 25 & 28 \\
\hline 2017 & 284 & 33 & 30 \\
\hline
\end{tabular}

Sumber : PT Telkom Akses Area Sumatera Utara Pematang Siantar

Dalam tabel 1 dapat dilihat tiga tahun terakhir jumlah karyawan yang keluar mengalami peningkatan. Dapat dilihat pada tahun 2015 karyawan yang keluar berjumlah 17 orang, tahun 2016 berjumlah 25 orang dan tahun 2017 berjumlah 33 orang. Hal ini membuktikan bahwa keinginan untuk tetap sebagai karyawan belum sepenuhnya dimiliki oleh semua karyawan. Ini menunjukkan bahwa komitmen organisasi PT Telkom Akses Area Sumatera Utara Pematang Siantar masih rendah.

Untuk melihat gambaran tentang disiplin kerja, penulis menampilkan keadaan absensi karyawan pada PT Telkom Akses Area Sumatera Utara Pematang Siantar 
Volume 20 Nomor 2, September 2020

Tabel 2:Daftar Absensi karyawanPada Tahun 2015-2017

\begin{tabular}{|l|c|c|c|c|c|c|c|c|c|}
\hline \multirow{2}{*}{ Tahun } & \multicolumn{6}{|c|}{ Absensi } & \multirow{2}{*}{$\begin{array}{c}\text { Total } \\
\text { Karyawan }\end{array}$} \\
\cline { 2 - 11 } & \multicolumn{2}{|c|}{ Sakit } & \multicolumn{2}{|c|}{ Izin } & \multicolumn{2}{c|}{ Terlambat } & \multicolumn{2}{c|}{ Mangkir } & 275 \\
\hline 2015 & 17 & $6,18 \%$ & 14 & $5,09 \%$ & 16 & $5,81 \%$ & 16 & $5,81 \%$ & 281 \\
\hline 2016 & 18 & $6,40 \%$ & 20 & $7,11 \%$ & 13 & $4,62 \%$ & 18 & $6,40 \%$ & 281 \\
\hline 2017 & 15 & $5,28 \%$ & 13 & $4,57 \%$ & 17 & $5,98 \%$ & 23 & $8,09 \%$ & 284 \\
\hline
\end{tabular}

Sumber : PT Telkom Akses Area Sumatera Utara Pematang Siantar

Berdasarkan tabel 2 dapat dilihat bahwa absensi karyawan yang mangkir dari Tahun 2015-2017 mengalami peningkatan. Hal ini dapat dilihat pada tahun 2015 sebesar 5,81\%, tahun 2016 sebesar 6,40\% dan tahun 2017 sebesar 8,09. Dapat dikatakan bahwa akibat dari banyaknya ketidakhadiran karyawan PT Telkom Akses Area Sumatera Utara Pematang Siantar yang tidak beralasan berdampak pada tanggung jawab yang diberikan mengalami penurunan. Pada tahun 2015 karyawan yang terlambat sebesar 5,81\%, kemudian turun di tahun 2016 sebesar 4,62\%, kemudian naik lagi ditahun 2017 sebesar 5,98\%. Hal ini menunjukkan disiplin kerja karyawan dikatakan buruk. Selain itu berdasarkan wawancara yang dilakukan dengan manajer, masih ada karyawan yang tidak disiplin mengikuti upacara dan apel kesiapan kerja bulanan.

Untuk melihat disiplin kerja karyawan juga bisa dilihat dari tanggung jawab yang diberikan perusahaan kepada karyawan. Pencapaian target yang ditentukan kepada setiap individu dapat dilihat melalui Nilai kerja Individu.

Prestasi kerja karyawan pada PT Telkom Akses Area Sumatera Utara Pematang Siantar dilihat dari rata-rata pencapaian setiap karyawan dibandingkan dengan target. Berdasarkan wawancara dengan manajer Provisioning dan Migration Pematang Siantar, menyatakan bahwa banyak work order yang harus diselesaikan oleh para teknisi setiap harinya. setiap teknisi harus mampu melayani minimal 5 (lima) konsumen per hari dalam hal pemasangan kabel dan menangani keluhan konsumen. Berikut adalah rata-rata pencapaian kerja karyawan dan rata-rata target karyawan PT Telkom Akses Area Sumatera Utara Pematang Siantar :

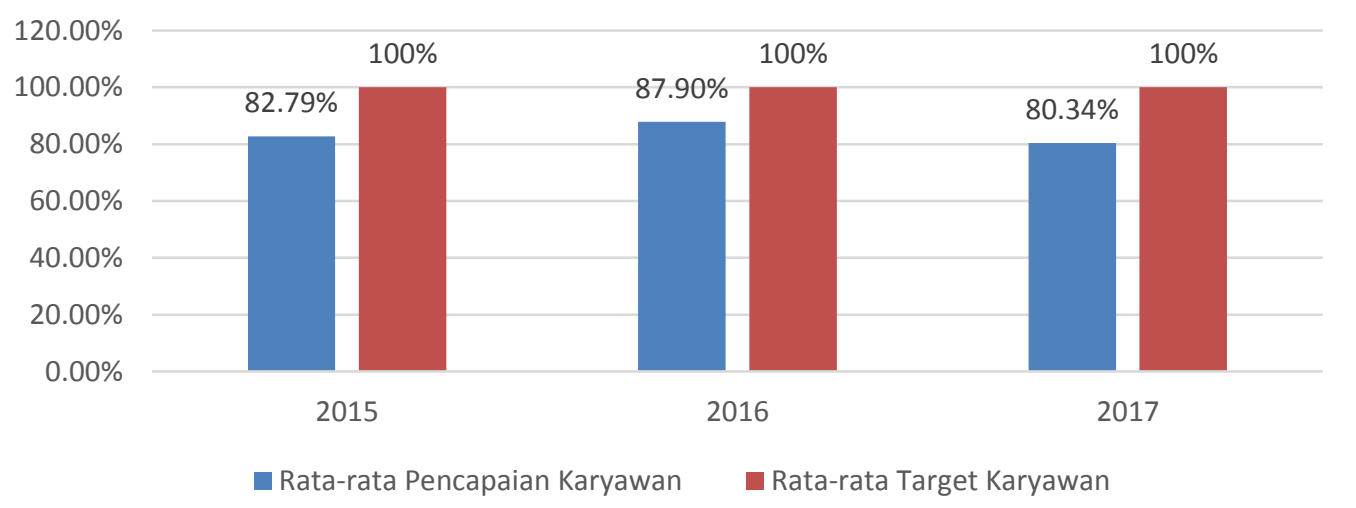

Gambar 1 Rata-rata Pencapaian Kerja Karyawan Dan Rata-rata Target Karyawan Pada PT Telkom Akses Area Sumatera Utara Pematang Siantar Tahun 2015 - 2017

Sumber : PT. Telkom Akses Area Sumatera Utara Pematang Siantar

Dari gambar 1 dapat dilihat persentase nilai rata-rata kerja individu pada karyawan PT Telkom Akses Area Sumatera Utara Pematang Siantar pada tahun 2015 sebesar 82,79\%, tahun 2016 sebesar 87,90\% dan tahun 2017 sebesar 80,34\%. Dari hasil tersebut, terlihat bahwa rata-rata pencapaian karyawan tidak mencapai rata-rata target yang telah ditetapkan, bahkan terjadi penurunan nilai rata-rata kerja individu. penurunan ini terjadi pada tahun 2017 sebesar 7,56\% nilai rata-rata ini lebih rendah dari pada tahun 2015. 


\section{Volume 20 Nomor 2, September 2020}

Kinerja menjadi hal yang penting dalam sebuah perusahaan ketika dikaitkan dengan kegiatan dan aktifitas yang dilakukannya. Melalui kinerja, dapat diketahui hasil kerja atau prestasi kerja yang telah dilakukan oleh karyawan. Prestasi kerja karyawan merupakan salah satu faktor penentu tercapainya tujuan perusahaan. Karyawan yang memiliki prestasi kerja yang tinggi diharapkan dapat memberikan kontribusi yang sangat baik bagi perusahaan, oleh karena itu PT Telkom Akses Area Sumatera Utara Pematang Siantar sangat memperhatikan prestasi kerja karyawannya, dengan prestasi kerja yang tinggi menunjukkan kualitas sumber daya manusia yang dimiliki oleh perusahaan, guna memperoleh pemanfaatannya secara optimal bagi perusahaan.

\section{KAJIAN TEORITIS}

\section{Komitmen Organisasional}

Menurut Mathis dan Jackson (2008:155) komitmen organisasional adalah derajat yang mana karyawan percaya dan menerima tujuan-tujuan organisasi dan akan tetap tinggal atau tidak akan meninggalkan organisasi. Luthans (2006,) menyebutkan bahwa komitmen organisasional merupakan sikap yang merefleksikan loyalitas karyawan pada organisasi dan proses berkelanjutan di mana anggota organisasi mengekspresikan perhatiannya terhadap organisasi dan keberhasilan serta kemajuan yang berkelanjutan.

Newstrom (1989) melanjutkan bahwa secara konseptual, komitmen organisasi ditandai oleh tiga hal:

1. Adanya rasa yang kuat dan penerimaan seseorang terhadap tujuan dan nilai-nilai organisasi

2. Adanya keinginan seseorang untuk melakukan usaha secara sungguh-sungguh dalam organisasi.

3. Adanya hasrat yang kuat untuk mempertahankan keanggotaan dalam suatu organisasi.

Dari defenisi para ahli di atas, dapat disimpulkan bahwa komitmen organisasional adalah suatu keadaan dimana seorang karyawan memihak organisasi tertentu serta tujuantujuan dan keinginannya untuk mempertahankan keanggotaannya dalam organisasi tersebut. Yang menunjukkan bahwa karyawan yang memiliki komitmen tinggi memiliki nilai absensi yang rendah dan memiliki masa bekerja yang lebih lama dan cenderung untuk bekerja lebih keras serta menunjukkan prestasi yang lebih baik.

Indikator Komitmen Organisasional

Menurut Allen dan Meyer dalam Robbins (2012:99) terbagi atas tiga komponen indikator komitmen organisasional, yaitu:

1. Komitmen Afektif yaitu berkaitan dengan emosional, identifikasi dan keterlibatan karyawan di dalam suatu organisasi.

2. Komitmen Normatif yaitu perasaan karyawan tentang kewajiban yang harus diberikan kepada organisasi.

3. Komitmen Berkelanjutan yaitu berarti komponen yang berdasarkan persepsi karyawan tentang kerugian yang akan dihadapinya jika meninggalkan organisasi.

Disiplin Kerja

Menurut Rivai (2004:825) disiplin kerja adalah suatu alat yang digunakan para manajer untuk berkomunikasi dengan karyawan agar mereka bersedia untuk mengubah suatu perilaku serta sebagai suatu upaya untuk meningkatkan kesadaran dan kesediaan seseorang menaati semua peraturan perusahaan dan norma-norma sosial yang berlaku.

Menurut Fathoni (2006:177) kedisiplinan harus ditegakkan karena dengan kedisiplinan tersebut dapat diharapkan pekerjaan akan dilakukan seefektif dan seefisien mungkin. Dan demikian pula jika kedisiplinan itu tidak dapat ditegakkan maka secara otomatis tujuan perusahaan tidak akan tercapai efektif dan efisien. Kedisiplinan merupakan 


\section{Volume 20 Nomor 2, September 2020}

fungsi operatif yang penting karena semakin baik disiplin karyawan, semakin tinggi prestasi kerja yang dicapai.

Berdasarkan pendapat para ahli di atas, dapat di simpulkan bahwa disiplin adalahkesadaran dan kesediaan seseorang menaati semua peraturan perusahaan dan normanorma sosial yang berlaku. Kedisiplinan harus ditegakkan dalam suatu organisasi perusahaan. Tanpa dukungan disiplin karyawan yang baik, sulit bagi perusahaan untuk mewujudkan tujuannya. Jadi, kedisiplinan adalah kunci keberhasilan suatu perusahaan dalam mencapai tujuannya.

Indikator-indikator Disiplin Kerja

Menurut Saydam (2005:284) indikator yang mempengaruhi tingkat kedisiplinan karyawan dalam suatu organisasi sebagai berikut:

1. Tanggung jawab yaitu kemampuan dalam menjalankan tugas dan peraturan perusahaan.

2. Sikap yaitu peraturan dasar tentang berpakaian dan bertingkah laku dalam melaksanakan pekerjaan.

3. Norma yaitu peraturan tentang apa yang boleh dan apa yang tidak boleh dilakukan oleh para karyawan selama dalam perusahaan dan sebagai acuan dalam bersikap.

Menurut Soejono (2000:125) indikator disiplin kerja yakni:

1. Ketepatan waktu. Para karyawan datang kekantor tepat waktu, tertib dan teratur, dengan begitu dapat dikatakan disiplin kerja baik.

2. Menggunakan peralatan kantor dengan baik. Sikap hati-hati dalam menggunakan peralatan kantor dapat mewujudkan bahwa seseorang memiliki disiplin kerja yang baik, sehingga peralatan kantor dapat terhindar dari kerusakan.

3. Tanggung jawab yang tinggi. Karyawan yang senantiasa menyelesaikan tugas yang dibebankan kepadanya sesuai dengan prosedur dan bertanggungjawab atas hasil kerja, dapat pula dikatakan memiliki disiplin kerja yang baik.

4. Ketaatan terhadap aturan kantor. Karyawan memakai seragam kantor, menggunakan kartu tanda pengenal/identitas, membuat ijin bila tidak masuk kantor, juga merupakan cerminan dari disiplin yang tinggi.

\section{Prestasi Kerja}

Menurut Sutrisno (2011:151) bahwa prestasi kerja adalah sebagian kerja merupakan hasil kerja yang telah dicapai seseorang karyawan sesuai dengan kriteria yang telah ditetapkan perusahaan dalam melaksanakan tugas dan tanggung jawabnya. Prestasi kerja mempunyai peranan yang sangat penting dalam mewujudkan tujuan perusahaan, prestasi kerja dapat diketahui sebagai satu hasil kerja yang dicapai seseorang dalam melaksanakan tugas-tugas dan wewenang yang diberikan kepada karyawan didasarkan atas kecakapan, pengalaman, kesunggunhan serta waktu. Prestasi kerja ini merupakan gabungan dari tiga faktor penting yaitu kemampuan dan minat seorang karyawan, kemampuan dan penerimaan atas pelaksanaan delegasi tugas, serta peran dan tingkat motivasi seorang karyawan.

Tinggi rendahnya suatu prestasi kerja tergantung dari atasan langsung dalam memberikan motivasi terhadap bawahannya agar memiliki prestasi kerja yang baik, oleh karena itu diperlukan kemampuan dan keahlian khusus dari pimpinan dalam hal meningkatkan prestasi kerja bawahannya dengan cara mempengaruhi dan mengarahkan para karyawan untuk bisa mencapai tujuan yang diharapkan oleh perusahaan.

Prestasi kerja merupakan hasil kerja yang dicapai sesorang. Istilah prestasi kerja berasal kata Job Performance yaitu prestasi kerja atau Actual Performance yaitu prestasi sesungguhnya yang dicapai oleh seseorang. Prestasi kerja juga merupakan hasil kerja yang 


\section{Volume 20 Nomor 2, September 2020}

dicapai dalam melaksanakan tugas yang dibebankan kepada yang dihasilkan atas kecakapan, pengalaman dan kesungguhan.

Maka dapat disimpulkan bahwa prestasi kerja adalah kegiatan dan hasil kerja yang dicapai atau ditunjukan oleh seseorang didalampelaksanaan tugas pekerjaan.

Indikator-indikator Prestasi Kerja

Nasution (2000:99), menyatakan bahwa ada beberapa indicator dalam prestasi kerja antara lain :

1. Kualitas kerja. Mutu seorang karyawan atau karyawan dalam hal melaksanakan tugastugasnya.

2. Kuantitas kerja. Segala macam bentuk satuan ukuran yang berhubungan dengan jumlah hasil kerja.

3. Inisiatif. Kriteria penilaiannya adalah selalu aktif atau semangat menyelesaikan pekerjaan tanpa menunggu perintah atasan artinya tidak pasif atau bekerja atas dorongan dari atasan.

4. Kerjasama. Kriteria penilaian ini adalah kemampuan menyesuaikan diri serta kemampuan untuk memberi bantuan kepada karyawān lain dalam batas kewenangannya.

\section{METODE PENELITIAN}

Populasi dalam penelitian ini adalah seluruh karyawan tetap PT Telkom Akses Area Sumatera Utara Pematang Siantar sebanyak 284 orang.Jumlah sampel dalam penelitian ini berjumlah 166 orang yang diperoleh dengan menggunakan metode Proportional random samplingdengan menggunakan rumus sebagai berikut:

$$
\begin{aligned}
& \mathbf{n}=\frac{\mathbf{N}}{\mathbf{1 + \mathbf { N e } ^ { 2 }}} \\
& \mathbf{n}=\frac{\mathbf{2 8 4}}{\mathbf{1 + 2 8 4}\left(\mathbf{0 . 0 5}^{2}\right)}=166 \text { Responden }
\end{aligned}
$$

Jumlah sampel sebanyak 166 responden.

\begin{tabular}{|c|c|c|c|}
\hline Variabel & Defenisi Variabel & Indikator & Skala \\
\hline $\begin{array}{l}\text { Komitmen } \\
\text { Organisasi } \\
\text { (X1) }\end{array}$ & $\begin{array}{l}\text { Keadaan yang menggambarkan sikap atau } \\
\text { kemauan karyawan untuk menyerahkan } \\
\text { semua kemampuannya untuk PT Telkom } \\
\text { Akses Area Sumatera Utara Pematang Siantar }\end{array}$ & $\begin{array}{ll}\text { 1. } & \text { Komitmen Afektif } \\
\text { 2. } & \text { Komitmen Normatif } \\
\text { 3. } & \text { Komitmen } \\
& \text { Berkelanjutan }\end{array}$ & Likert \\
\hline $\begin{array}{l}\text { Disiplin } \\
\text { Kerja (X2) }\end{array}$ & $\begin{array}{l}\text { Suatu alat yang digunakan para manajer untuk } \\
\text { berkomunikasi dengan karyawan agar mereka } \\
\text { bersedia untuk mengubah suatu perilaku serta } \\
\text { sebagai suatu upaya untuk } \\
\text { meningkatkankesadaran dan kesediaan } \\
\text { seseorang menaati semua peraturan } \\
\text { perusahaan dan norma-norma sosial yang } \\
\text { berlaku pada PT Telkom Akses Area Sumatera } \\
\text { Utara Pematang Siantar }\end{array}$ & $\begin{array}{ll}\text { 1. } & \text { Ketepatan waktu } \\
\text { 2. } & \begin{array}{l}\text { Menggunakan } \\
\text { peralatan kantor } \\
\text { dengan baik }\end{array} \\
\text { 3. } & \text { Tanggung jawab } \\
\text { yang tinggi } \\
\text { 4. }\end{array}$ & Likert \\
\hline $\begin{array}{l}\text { Prestasi } \\
\text { Kerja }(\mathrm{Y})\end{array}$ & $\begin{array}{l}\text { Prestasi kerja adalah suatu hasil kerja secara } \\
\text { kualitas dan kuantitas yang dicapai oleh } \\
\text { seorang karyawan dalam melaksanakan } \\
\text { tugasnya sesuai dengan tanggung jawab yang } \\
\text { diberikan kepadanya pada PT Telkom Akses } \\
\text { Area Sumatera Utara Pematang Siantar }\end{array}$ & $\begin{array}{ll}\text { 1. } & \text { Kualitas kerja } \\
\text { 2. } & \text { Kuantitas kerja } \\
\text { 3. } & \text { Inisiatif } \\
\text { 4. } & \text { Kerjasama }\end{array}$ & Likert \\
\hline
\end{tabular}

\section{Tabel 3 Operasionalisasi Variabel}




\section{Teknik Analisis Data}

Uji Validitas dan Reliabilitas

Uji validitas dalam penelitian ini menggunakan analisis item yaitu mengkorelasikan skor tiap butir dengan skor total yang merupakan jumlah dari setiap skor butir. Jika ada item yang tidak memenuhi syarat, maka item tersebut tidak akan diteliti lebih lanjut. Syarat tersebut menurut sugiyono (2008) yang harus dipenuhi yaitu harus memiliki kriteria sebagai berikut:

a. Jika $r>0,30$, maka item-item pertanyaan dari kuesioner adalah valid.

b. Jika $r \leq 0,30$, maka item-item pertanyaan dari kuesioner adalah tidak valid.

\section{Uji Reliabilitas}

Perhitungan reliabilitas pada penelitian ini menggunakan analisis yang dikembangkan oleh Alpha Cronbach dengan kriteria pengujian sebagai berikut:

$\alpha>0,5$ artinya instrument reliabel $a \leq 0,5$ artinya instrument tidak reliabel

\section{Metode Analisis Regresi Berganda}

Metode analisi yang digunakan dalam penelitian adalah analisis regresi linear berganda dengan persamaan sebagai berikut:

$$
\mathrm{Y}=\mathbf{a}+\mathrm{b}_{1} \mathrm{X}_{1}+\mathrm{b}_{2} \mathrm{X}_{2}+\mathrm{e}
$$

\section{Uji Hipotesis}

Uji t digunakan untuk melihat pengaruh variabel bebas secara parsial terhadap variabel terikat dan uji $\mathrm{F}$ digunakan untuk mengetahui pengaruh variabel-variabel independen secara bersama-sama (simultan) terhadap variabel dependen (Ghozali, 2005) dengan kriteria keputusan: apabila nilai signifikansi $a>0,05$, maka hipoesis ditolak dan apabila nilai signifikansi $a \leq 0,05$, maka hipotesis diterima.

\section{Koefisien Determinasi $\left(\mathbf{R}^{2}\right)$}

Koefisien determinasi $\left(\mathrm{R}^{2}\right)$ pada intinya meñukur seberapa besar kemampuan model dalam menerangkan variabel terikat. Jika $\mathrm{R}^{2}$ semakin besar (mendekati satu), maka kemampuan variabel bebas $(\mathrm{X})$ dalam menjelaskan variabel terikat $(\mathrm{Y})$ semakin besar. Hal ini berarti model yang digunakan semakin kuat untuk menerangkan variasi variabel terikat dan sebaliknya.

\section{HASIL PENELITIAN DAN PEMBAHAN}

PT Telkom Akses (PTTA) merupakan anak perusahaan PT Telekomunikasi Indonesia, Tbk (Telkom) yang sahamnya dimiliki sepenuhnya oleh Telkom. PTTA bergerak dalam bisnis penyediaan layanan konstruksi dan pengelolaan infrasruktur jaringan. Pendirian PTTA merupakan bagian dari komitmen Telkom untuk menghadirkan akses informasi dan komunikasi tanpa batas bagi seluruh masyarakat Indonesia. PT Telkom Akses berupaya menghadirkan koneksi internet berkualitas dan terjangkau untuk meningkatkan kualitas sumber daya manusia sehingga mampu bersaing di level dunia. Saat ini PT Telkom Akses tengah membangun jaringan backbone berbasis Serat Optik maupun Internet Protocol (IP) dengan menggelar 30 node terra router dan sekitar $75.000 \mathrm{~km}$ kabel Serat Optik. Pembangunan kabel serat optik merupakan bagian dari program Indonesia Digital Network Terminal Equipment (NTE), serta Jasa Pengelolaan Operasi dan Pemeliharaan jaringan Akses Broadband. 


\section{Volume 20 Nomor 2, September 2020}

PT. Telkom Akses adalah anak perusahaan PT. Telekomunikasi Indonesia, Tbk yang bergerak dibidang konstruksi pembangunan dan manage service infrastruktur jaringan. PT. Telkom Akses didirikan pada tanggal 12 Desember 2012, dan sejak saat itu aktif dalam pekerjaan jasa konstruksi penggelaran jaringan akses broadband termasuk sebagai lessor penyediaan Network Terminal Equipment (NTE) serta menyediakan pekerjaan jasa Manage Service Operasi dan Pemeliharaan (OM, Operation \& Maintenance) jaringan akses broadband.

Berdasarkan tabel 7, model regresi linier berganda dapat dirumuskan sebagai berikut : $\mathrm{Y}=4.182+0.420\left(\mathrm{X}_{1}\right)+0.615\left(\mathrm{X}_{2}\right)+\mathrm{ei}$

Dimana

$$
\begin{array}{llll}
\mathrm{Y} & =\text { Prestasi Kerja } & \mathrm{a} & =\text { Konstanta } \\
\mathrm{X}_{1} & =\text { Komitmen Organisasional } & \mathrm{X}_{2} & =\text { Disiplin Kerja } \\
\mathrm{B}_{1-2} & =\text { Koefisien regresi } & \text { ei } & =\text { variabel pengganggu }
\end{array}
$$

Arti persamaan regresi linier berganda adalah :

1. Nilai konstanta (a) sebesar 4.182 artinya, jika komitmen organisasional dan disiplin kerja bernilai 0, maka prestasi kerja karyawan sebesar 4.182.

2. Koefisien regresi Komitmen Organisasional $=0.420$ artinya jika variabel komitmen organisasional ditingkatkan satu satuan maka prestasi kerja meningkat sebesar 0,420 Satuan.

3. Koefisien regresi disiplin kerja $=0.615$ artinya jikavariabel disiplin kerja ditingkatkan satu satuan maka prestasi kerja akan meningkat sebesar 0.615 satuan

Tabel 4. Koefisien Determinasi $\left(\mathbf{R}^{2}\right)$

\begin{tabular}{|l|r|r|r|r|}
\hline Model & \multicolumn{1}{|c|}{$\mathrm{R}$} & \multicolumn{1}{|c|}{ R Square } & Adjusted R Square & \multicolumn{1}{c|}{ Std. Error of the Estimate } \\
\hline 1 & $.906^{\mathrm{a}}$ & .820 & .818 & 1.410 \\
\hline
\end{tabular}

a. Predictors: (Constant), X2, X1

Sumber : Data diolah dengan program SPSS

Tabel 4 menunjukkan koefisien determinasi (R Square) adalah sebesar 0.820 atau $82 \%$ artinya variasi prestasi kerja karyawan dapat dijelaskan oleh variasi komitmen organisasional dan disiplin kerja sebesar $82 \%$ dan sisanya $18 \%$ dapat dijelaskan oleh variabel lain yang tidak termasuk dalam penelitian ini. seperti motivasi, kepemimpinan dan pelatihan.

Penelitian ini dilakukan pada PT Telkom Akses Area Sumatera Utara Pematang Siantar yang beralamat di jalan Asahan Km 3,5 Pematang Siantar dengan sampel sebesar 166 responden. Teknik pengambilan sampel yang digunakan dalam penelitian ini adalah Propotional Random Sampling yaitu pengambilan sampel yang berdasarkan strata. Penentuan strata dalam penelitianini berdasarkan jenis kelamin, umur, pendidikan, departemen atau devisi dan lama bekerja. Pengambilan sampel juga menggunakan rumus Slovin.

Variabel komitmen organisasional, tingkat signifikansinya sebesar $0.000<\alpha(0.05)$ sehingga dapat disimpulkan bahwa secara parsial variabel komitmen organisasional berpengaruh positif dan signifikan terhadap prestasi kerja karyawan pada PT Telkom Akses Area Sumatera Utara Pematang Siantar.

Variabel disiplin kerja, tingkat signifikansinya $0.000<a(0.05)$ sehingga dapat disimpulkan bahwa secara parsial disiplin kerja berpengaruh positif dan signifikan terhadap prestasi kerja karyawan pada PT Telkom Akses Area Sumatera Utara Pematang Siantar.

Hasil penelitian ini sesuai dengan teori yang dikemukakan oleh Fathoni (2006:177) kedisiplinan harus ditegakkan karena dengan kedisiplinan tersebut dapat diharapkan pekerjaan akan dilakukan seefektif dan seefisien mungkin. Dan demikian pula jika kedisiplinan itu tidak dapat ditegakkan maka secara otomatis tujuan perusahaan tidak akan tercapai efektif dan efisien. Kedisiplinan merupakan fungsi operatif yang penting karena semakin baik disiplin karyawan, semakin tinggi prestasi kerja yang dicapai. Untuk itu perlu 


\section{Volume 20 Nomor 2, September 2020}

meningkatkan disiplin karyawan tersebut, ketepatan waktu, menggunakan peralatan kantor dengan baik, tanggungjawab yang tinggi dan ketaatan terhadap peraturan kantor.

Berdasarkan hasil analisis data, pada uji $\mathrm{F}$ diperoleh tingkat signifikan $0,000<\alpha$ $(0,05)$, sehingga dapat disimpulkan bahwa secara simultan variabel komitmen orgnisasional dan disiplin kerja berpengaruh signifikan terhadap prestasi kerja karyawan pada PT Telkom Akses Area Sumatera Utara Pematang Siantar.

Berdasarkan hasil uji analisis regresi linier berganda dapat dirumuskan sebagai berikut : $\mathrm{Y}=4.182+0.420\left(\mathrm{X}_{1}\right)+0.615\left(\mathrm{X}_{2}\right)+$ e. Dari persamaan regresi tersebut dapat diketahui bahwa variabel bebas yang mempunyai pengaruh paling besar terhadap prestasi kerja karyawan adalah didisplin kerja karena memiliki koefisien regresi paling besar yaitu 0,615 .

\section{KESIMPULAN DAN SARAN}

\section{Kesimpulan}

Berdasarkan hasil analisis dan pembahasan yang telah dilakukan, maka dapat ditarik kesimpulan sebagai berikut:

1. Persamaan regresi linier berganda yang diperoleh adalah $Y=4.182+0.420\left(X_{1}\right)+0.615$ $\left(\mathrm{X}_{2}\right)+$ e. Artinya komitmen organisasional dan disiplin kerja berpengaruh positif terhadap prestasi kerja karyawan pada PT Telkom Akses Area Sumatera Utara Pematang Siantar. Hal ini dapat dilihat dari nilai koefisien regresinya yang bertanda positif.

2. Berdasarkan uji thitung untuk variabel komitmen organisasional dan variabel disiplin kerja memiliki tingkat signifikansi sebesar $0.000<0.05$ sehingga dapat disimpulkan bahwa secara parsial variabel komitmen organisasional dan variabel disiplin kerja berpengaruh positif dan signifikan terhadap prestasi kerja karyawan pada PT Telkom Akses Area Sumatera Utara Pematang Siantar. Berdasarkan uji F, variabel komitmen organisasional dan variabel disiplin kerja berpengaruh signifikan terhadap prestasi kerja karyawan pada PT Telkom Akses Area Sumatera Utara Pematang Siantar. Hal tersebut dapat dilihat dari nilai signifikansi $\mathrm{F}(0.000)<a(0.05)$.

3. Koefisien determinasi $\mathrm{R}^{2}$ adalah sébesar 0.820. Artinya model mampu menjelaskan Prestasi Kerja sebesar $82 \%$ dan sisanya $18 \%$ dijelaskan oleh variabel lain yang tidak termasuk dalam penelitian ini.

\section{Saran}

Berdasarkan kesimpulan diatas dapat dikemukakan saran sebagai berikut :

1. Sebaiknya pimpinan PT Telkom Akses Area Sumatera Utara Pematang Siantar dapat meningkatkan komitmen yang dimiliki oleh Karyawan sehingga prestasi kerja mereka sesuai target.

2. Disiplin Kerja perlu ditingkatken untuk memperbaiki prestasi kerja karyawan PT Telkom Akses Area Sumatera Utara Pematang Siantar.

\section{DAFTAR PUSTAKA}

Luthans, Fred. 2006 . Organizational Behavior, Me Graw Hill, Inc, San Fransisco, New York, USA.

Mathis, Robert L, dan John H. Jackson. 2008. Manajemen Sumber Daya Manusia, Buku 1. Jakarta: Salemba Empat.

Robbins, Stephen P, 2012. Perilaku Organisasi. Edisi delapan. Hadayana Pujatmana, Jakarta. 
Rivai, Veithzak. 2004. Manajemen Sumber Daya Manusia Untuk Perusahaan. Cetakan 1. Jakarta : Murai Kencana.

Sutrisno, Edy. 2011. Desain Penelitian Manajemen Sumber Daya Manusia dan Penilaian Karyawan. Jakarta : Raja Grafindo Persada.

Soejono. 2000. Manajemen Sumber Daya Manusia. Jakarta : Bumi Aksara.

Sutrisno. 2009. Manajemen Sumber Daya Manusia. Jakarta: Kencana Pranada Media Group. Sugiyono. 2008. Metode Penelitian Kuantitatif kualitatif dan RED. Bandung: Alfabeta.

Ana Puspita. 2013. Pengaruh Komitmen Organisasional, Disiplin Kerja terhadap Prestasi Kerja KaryawanpadaDinas Kebersihan dan Pertamanan Surakarta.

Dwi Irawati. 2012. Pengaruh Komitmen Organisasional, Disiplin Kerja dan Motivasi Kerja Terhadap Prestasi Kerja Karyawan Balai Pelaksana Teknis Bina Marga Wilayah Magelang.

Dyah Ayu. 2014. Pengaruh Komitmen Organisasional, Disiplin Kerja Karyawan terhadap Prestasi Kerja Karyawan pada PT Pabrik Gula Toelangan Sidoarjo Irfan Nanda. 2013. Pengaruh Komitmen Organisasi Terhadap Prestasi Kerja pada Karyawan AJB Bumi Putera Kantor Cabang Batu.

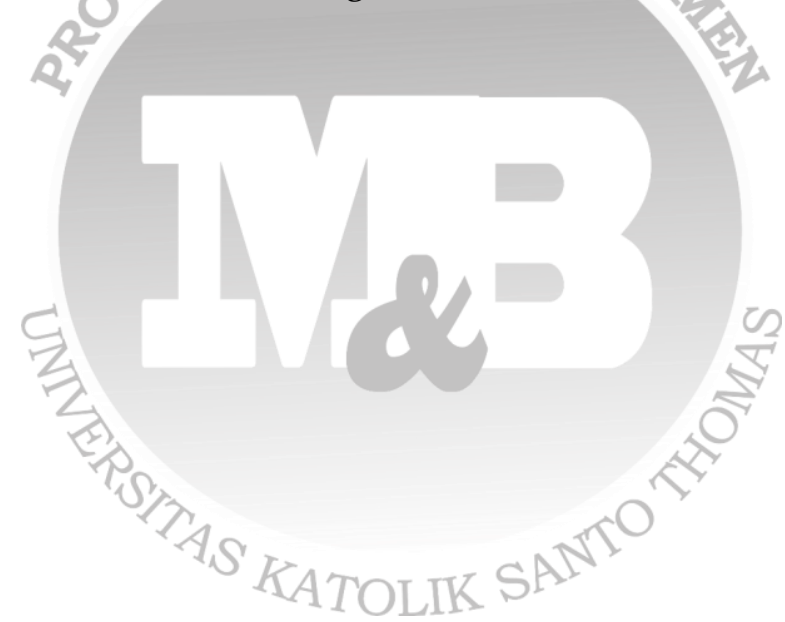

